\title{
The Accuracy of Directive Speech Act Responding Command Turn Taking in Game of Thrones Novel
}

\author{
Yoana Gita Pradnya Lengari; M. R. Nababan; Djatmika \\ Linguistic (Translation) Program, Postgraduate Faculty, Universitas Sebelas Maret, Indonesia
}

http://dx.doi.org/10.18415/ijmmu.v6i2.717

\begin{abstract}
This study aims to describe the translation techniques and quality of translation in the aspect of accuracy of command turn taking utterances using pragmatic approach. This is a descriptive qualitative research with embedded case study. The data collection techniques used in this research is document analysis, Focus Group Discussion (FGD), as well as questionnaire to decide on the translation technique and the quality of translation. The data which is used are utterance sentences containing command turn taking and its directive speech act responses in George R. R. Martin's Game of Thrones novel and its translation. The result indicates that the translator uses established equivalent, variation, explication, borrowing, modulation, literal translation, transposition, implicitation, discursive creation, and generalization to translate the sentences. In terms of accuracy, the average rate of the translation is 2.6 out of 3. The score indicate that the translation of directive speech act in response to command turn taking in Game of Thrones novel have equivalent meaning from the source text to the target text.
\end{abstract}

Keywords: Translation Techniques; Accuracy; Speech Act; Translation

\section{Introduction}

Language is one of the most important aspects of communication. However, due to the differences languages that people use all over the world has become a barrier in communication process. Language translation becomes one of the most effective ways to overcome that situation. Nida and Taber (1982) described translation as replacing or to producing a text with another text of foreign language which is equivalent in terms of semantic or meaning and style. In dealing with translation, there are many things to be considered in order to deliver the right message from the source language to target language. Translator has to consider that translating is a complex activity (Shaffner and Adab, 2000).

Pragmatic as a study of meaning in use or meaning in context dealing with the speaker meaning and utterance interpretation that represent the intentions and the goals of speaker or hearer can always be seen as one of the aspect that can influence the quality of a translation product. This article tries to explore the Command Turn in Game of Thrones novel. This is a translation studies based on pragmatic approach. The paper focuses on speech act which is the term to the dialogue between two persons or more tha consist of speaker and hearer (Yule: 1996). They can be classified into three categories which are locutionary acts, illocutionary acts, and perlocutionary acts. Searle (1979) classifies illocutionary acts into five categories, namely directive, commisive, assertive, expressive, and declarative. Directives are illocutionary acts that are attempted by the speaker to make the hearer do something, commands are one of the parts of directive speech (Searle, 1979). 
Moreover, Sarlito (1995) states that response can be categorized as a stimulus. Gulo (1996) strengthen the premise that response is a reaction or answer of stimulus or the result of stimulus. The forms of stimulus contain verbal responses and also non-verbal responses, but only the verbal responses will be discussed in this article.

This research is aimed at analyzing the verbal responses of command Turn in Game of Thrones Novel and its translation. The responses of command can be different in each speech act, and through this exploration, and the responses that will be discussed are the directive speech acts responding to command turn taking. Through this exploration, hopefully the readers could understand the types of translation techniques that are used in each speech act and their impacts to the translation quality in the target language.

\section{Methodology}

This research can be classified as a descriptive qualitative research with an embedded case study Sutopo (2002: 35) that is oriented on a translation product. The sources of data consist of documents which are selected with purposive sampling technique from Game of Thrones Novel and its translation and also from discussion results with informants.

The data of this research are taken from the conversation between the characters in Game of Thrones that contain directive speech acts responding to command turn taking in form of words. It can be identified from the speaker's utterances that contain command clauses and the sentences that the hearer responds after it. The accumulation of the data is analyzed with a content analysis in according to purposive sampling. According to Yin (Santosa, 2014), the technique of content analysis is the way to find various things as needed.

After collecting the data, the next step is to identify the translation techniques applied by the translator by using Molina and Albir (2002) techniques of translation from Source Text (ST) to Target Text (TT) such as literal translation, variation, modulation, established equivalent, explication, pure borrowing, generalization, implicitation, reduction, adaptation, transposition, discursive creation, particularization, and linguistic amplification.

After identifying the techniques applied, the next step is to find out the accuracy level of each data using Nababan's (2012) Translation Quality Assessment. This is to determine whether the techniques which are used by the translation affect the accuracy of the translation to the Target Text (TT).

Table 1:Assessment Instrument for Translation Accuracy(Nababan, 2012)

\begin{tabular}{lll}
\hline $\begin{array}{l}\text { Translation } \\
\text { Category }\end{array}$ & Score & Qualitative Parameter \\
\hline Accurate & 3 & $\begin{array}{l}\text { The meaning of words, technical terms, phrases, clauses, sentences, or } \\
\text { Text translated accurately into Target Text; without any distort } \\
\text { meaning. }\end{array}$ \\
\hline Quite Accurate 2 & $\begin{array}{l}\text { Most of the meaning of words, technical terms, phrases, clauses, senten } \\
\text { Source Text translated accurately into Target Text; although there is } \\
\text { distortion of meaning, double meaning translation, or omission that in } \\
\text { with the message. }\end{array}$ \\
\hline Not Accurate & 1 & $\begin{array}{l}\text { The meaning of words, technical terms, phrases, clauses, sentences, or } \\
\text { Texts are not accurately translated into Target Text or deleted in the } \\
\text { Text. }\end{array}$ \\
\hline
\end{tabular}




\section{Result and Discussion}

Based on the data that are collected from Game of Thrones Novel, there are some findings in the types of commanding turn. According to Searle (1979), commanding is a part of directive speech acts that are attempted by the speaker to make the hearer do something.

There are 27 data found in this research. From the collected data, it can be seen that most of the translation are considered as accurate with 25 accurate data which means 2.57 accuracy score. Only 2 data are considered quite accurate with 0.43 accuracy score and no data considered not accurate in the research.

Table 2: The Accuracy of the Translation of Directive Speech Acts Responding to Command Turn Taking

\begin{tabular}{lllll}
\hline Translation Qua & Data Number & Frequency & Percentage & Quality Score \\
\hline \multirow{2}{*}{ Accurate } & $010,013,058,082,120,150,137$, & & & \\
& $031,076,094,009,011,032,035$, & 25 & 92 & 2.57 \\
& $\begin{array}{l}037,044,056,065,066,125, \\
128,036,124,012,024\end{array}$ & & & \\
\hline Quite Accurate & 089,153 & 2 & 8 & 0.43 \\
\hline Not Accurate & - & 0 & 0 & 0 \\
\hline TOTAL & $\mathbf{2 7}$ & $\mathbf{1 0 0}$ & - \\
\hline
\end{tabular}

\section{Accurate}

In this level of translation quality, the percentage of data accuracy is quite high, which is $92 \%$ or 2.57 out of 3 in accuracy score. The example of the data which shows accurate score are shown below:

\section{Table 3. Data Sample 1:}

\begin{tabular}{|c|c|}
\hline Data No: 013/M/Bsu/114/Bsa/116 & \\
\hline $\begin{array}{l}\text { Ned's suspicion that Robert has appoint } \\
\text { proved to be real. He is afraid that Jan } \\
\text { Robert to reconsider his decision. }\end{array}$ & $\begin{array}{l}\text { ed his brother-in-law as the Warden of the } \\
\text { nie will betray Robert too. He tries to pe }\end{array}$ \\
\hline Source Text & Target Text \\
\hline $\begin{array}{l}\text { "Don't vex me about this, Ned, the sto } \\
\text { been set." }\end{array}$ & $\begin{array}{l}\text { "Jangan merecokiku soal ini, Ned, kep } \\
\text { sudah dibuat." }\end{array}$ \\
\hline “Your Grace, may I speak frankly?" & "Yang Mulia, boleh aku bicara jujur?" \\
\hline
\end{tabular}

The translation techniques used to respond to commanding speech act can be seen as follow:

Table 4:Translation Technique Data Sample 1

\begin{tabular}{lll}
\hline Source Text & Target Text & Translation Technique \\
\hline Your Grace, & Yang Mulia, & Established Equivalent \\
\hline may & boleh & Established Equivalent \\
\hline I & $a k u$ & Variation \\
\hline speak & bicara & Established Equivalent \\
\hline frankly & jujur & Established Equivalent \\
\hline
\end{tabular}


From data sample 1, the phrase "Don't vex me about this, Ned, the stone has been set" translated into "Jangan merecokiku soal ini, Ned, keputusan sudah dibuat" is considered as commanding speech act. The phrase is responded with another speech act "Your Grace, may I speak frankly?" that translated into "Yang Mulia, boleh aku bicara jujur?" Established Equivalent technique is mostly used to translate the phrase. The raters agreed that the speech act above is considered as accurate because the meaning from the source text is delivered correctly and clearly into target text and it fits the context of the situation.

Table 5: Data sample 2:

Data No: $128 / \mathrm{M} / \mathrm{BSu} / 557 / \mathrm{BSa} / 625$

An argument rises after Ghost brings a piece of human hand to Jon and his group. They camp filled with dead bodies.

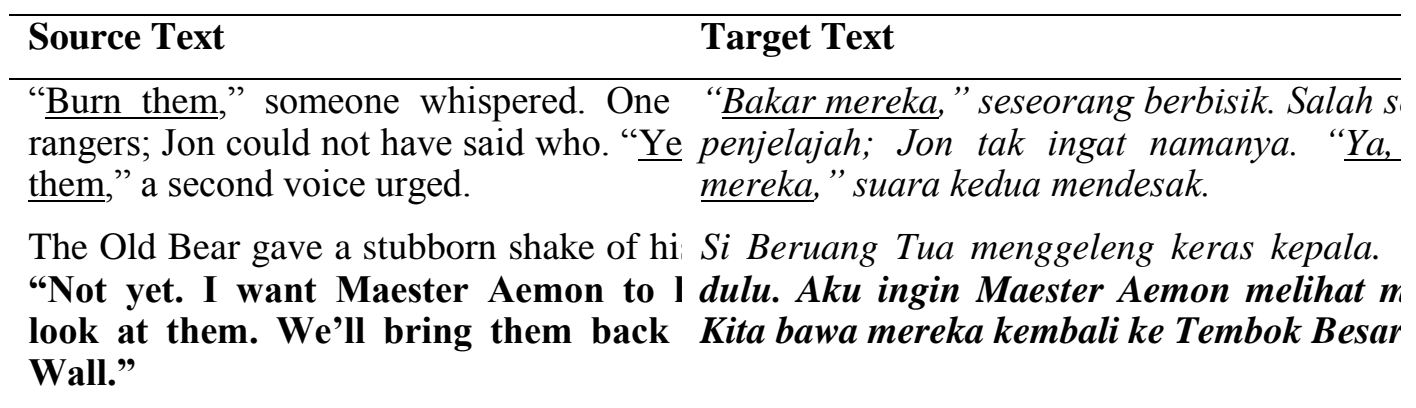

Table 6:Translation Techniques Used in Data Sample 2

\begin{tabular}{lll}
\hline Source Text & Target Text & Translation Technique \\
\hline not yet & nanti dulu & Established Equivalent \\
\hline I & aku & Variation \\
\hline want & ingin & Established Equivalent \\
\hline Maester Aemon & Maester Aemon & Pure Borrowing \\
\hline to have a look at & melihat & Established Equivalent \\
\hline them & mereka & Established Equivalent \\
\hline we'll & kita & Established Equivalent \\
\hline bring & bawa & Established Equivalent \\
\hline them & mereka & Established Equivalent \\
\hline back to & kembali ke & Established Equivalent \\
\hline the Wall & Tembok Besar & Explication \\
\hline
\end{tabular}

From data sample 2, the respond to commanding speech act "Burn them" which translated into "Bakar mereka" is "Not yet. I want Maester Aemon to have a look at them. We'll bring them back to the Wall." and this respond is translated into "Nanti dulu. Aku ingin Maester Aemon melihat mereka. Kita bawa mereka kembali ke Tembok Besar." This speech act is considered as commanding that include in the directive speech act. The techniques which are used to translate the phrase are established equivalent for the "not yet," translated into "nanti dulu," "want" translated into "ingin," "to have a look at them," translated into "melihat mereka," and "we'll bring them back" which translated into "kita bawa mereka 
kembali." The translator also used pure borrowing technique to translate "Maester Aemon," variation to translate "I" into "Aku" and also explication technique to translate "The Wall" into "Tembok Besar."

The raters agreed that the speech act above is considered as accurate because the meaning from the source text is delivered correctly and clearly into target text and it fits the context of the situation. The techniques which are frequently used to translate this phrase is established equivalent.

Table 7: Data sample 3:

Data No: 076/M/BSu/772/BSa/870

After hearing that his father has been murdered, Jon wants to go back to Winterfell t along with their brothers, but his friends don't allow him to leave the Wall.

\begin{tabular}{|c|c|c|}
\hline Source Text & Target Text & \\
\hline "Get out of my way, Sam." & "Jangan halangi jalanku, Sam." & \\
\hline “Jon, you can't," Sam said. "I won't let y & $\begin{array}{l}\text { “Jon, jangan," Sam berkata. } \\
\text { membiarkanmu." }\end{array}$ & “ $A k u$ \\
\hline
\end{tabular}

Table 8:Translation Techniques Used in Data Sample 3

\begin{tabular}{lll}
\hline Source Text & Target Text & Translation Technique \\
\hline Jon & Jon & Variation \\
\hline you can't & jangan & Established Equivalent \\
\hline I & $A k u$ & Variation \\
\hline won't & takkan & Established Equivalent \\
\hline let you & membiarkanmu & Established Equivalent \\
\hline
\end{tabular}

From data sample 3, the respond to commanding speech act "Get out of my way, Sam."which translated into "Jangan halangi jalanku, Sam." is "Jon, you can't, I won't let you" and this respond is translated into "Jon, jangan, aku takkan membiarkanmu." This speech act is considered as commanding that include in the directive speech act. The techniques which are used to translate the phrase are established equivalent for the "you can't," translated into "jangan," "won't" translated into "takkan" "let you," translated into "membiarkanmu." The translator also used variation technique to translate "Jon," and "I" into "Aku."

The raters agreed that the speech act above is considered as accurate because the meaning from the source text is delivered correctly and clearly into target text and it fits the context of the situation. The techniques which are frequently used to translate this phrase are established equivalent and variation.

\section{Quite Accurate}

While we can see that the majority of the data is considered as accurate, there are still 2 (two) data which are considered as quite accurate. In this level of translation quality, the percentage of data accuracy is low, which is $8 \%$ or 0.43 out of 3 in accuracy score. The example of the data which shows quite accurate score is shown below: 
Table 9: Data sample 3

Data No: 089/M/BSu/125/BSa/128

Jon's anger against Tyrion makes his wolf attacks Tyrion. Tyrion asks Jon to help ce wolf.

\begin{tabular}{ll}
\hline Source Text & Target Text \\
\hline "Ask me nicely." & "Mintalah baik-baik." \\
"I should be very grateful for youl & "Aku akan sangat berterima kasih \\
assistance, Jon." he said mildly. & bantuanmu yang murah hati, Jon," katanya \\
\hline
\end{tabular}

Table 10:Translation Techniques Used in Data Sample 3

\begin{tabular}{lll}
\hline Source Text & Target Text & Translation Technique \\
\hline I & Aku & Variation \\
\hline should be & akan & Modulation \\
\hline very & sangat & Establish Equivalent \\
\hline grateful & berterima kasih & Establish Equivalent \\
\hline for & untuk & Establish Equivalent \\
\hline your & mu & Variation \\
\hline kind assistance & bantuan yang murah hati & Literal \\
\hline Jon & Jon & Pure Borrowing \\
\hline
\end{tabular}

From the discussion, the raters agreed that the speech act above is considered as quite accurate. The use of literal technique in translating the text affect the quality of the translation because the meaning from the source text is not delivered correctly and clearly into target text even though it fits the context of the situation. The techniques which are frequently used to translate this phrase are established equivalent.

Table 11. Data Sample 4:

Data No: $153 / \mathrm{M} / \mathrm{BSu} / 802 / \mathrm{BSa} / 905$

The funeral ceremony for Khal Drogo will start, after she distribute prizes to her sc the Khaleesi wants to put her dragon eggs and burn herself in the funeral pyre.

\begin{tabular}{|c|c|}
\hline Source Text & Target Text \\
\hline "Bring my eggs," & "Ambilkan telur-telurku," \\
\hline $\begin{array}{l}\text { Ser Jorah took her arm. "My queen, } \\
\text { will have no use for dragon's eggs } \\
\text { night lands. Better to sell them in } f \\
\text { Sell one and we can buy a ship to } t \\
\text { back to the Free Cities. Sell all thr' } \\
\text { you will be a wealthy woman all } \\
\text { days." }\end{array}$ & $\begin{array}{l}\text { Ser Jorah menggandeng tangannya. "R } \\
\text { Drogo tak butuh telur naga di kerajaan } n \\
\text { Lebih baik dijual di Asshai. Jual satu da } \\
\text { bisa membeli kapal untuk membawa kita k } \\
\text { ke Kota-kota Merdeka. Jual ketiganya da } \\
\text { akan menjadi perempuan kaya sampai } \\
\text { hayatmu." }\end{array}$ \\
\hline
\end{tabular}


From data sample 4, the translation techniques used to respond to commanding speech act can be seen as follow:

Table 12:Translation Technique Used in Data Sample 4

\begin{tabular}{|c|c|c|}
\hline Source Text & Target Text & Translation Technique \\
\hline My & $k u$ & Pure borrowing \\
\hline Queen & Ratu & Variation \\
\hline Drogo & Drogo & Pure Borrowing \\
\hline will have no use for & tak butuh & Established Equivalent \\
\hline dragon's eggs & telur naga & Established Equivalent \\
\hline in & $d i$ & Established Equivalent \\
\hline the night lands & kerajaan malam & Established Equivalent \\
\hline better to & Lebih baik & Established Equivalent \\
\hline sell them & dijual & Modulation \\
\hline in & $d i$ & Established Equivalent \\
\hline Asshai & Asshai & Pure Borrowing \\
\hline sell & Jual & Established Equivalent \\
\hline one & satu & Established Equivalent \\
\hline and & dan & Established Equivalent \\
\hline we & kita & Established Equivalent \\
\hline can & bisa & Established Equivalent \\
\hline buy & membeli & Established Equivalent \\
\hline a ship & kapal & Established Equivalent \\
\hline to take & untuk membawa & Established Equivalent \\
\hline us & kita & Established Equivalent \\
\hline back to & kembali ke & Established Equivalent \\
\hline The Free Cities & Kota-kota Merdeka & Literal \\
\hline sell & Jual & Established Equivalent \\
\hline all three & ketiganya & Established Equivalent \\
\hline and & dan & Established Equivalent \\
\hline you & kau & Variation \\
\hline will be & akan menjadi & Established Equivalent \\
\hline a wealthy woman & perempuan kaya & Established Equivalent \\
\hline all your days & sampai akhir hayatm & Modulation \\
\hline
\end{tabular}

The raters agreed that the speech act above is considered as quite accurate. This data is rated 2 by all three raters. Although establish equivalent technique is mostly used in translating the text, the use of 
literal technique affects the quality of the translation because the meaning from the source text is not delivered correctly and clearly into target text even though it fits the context of the situation. The translator should consider avoiding using literal technique to produce an accurate message in the target text.

\section{Conclusion}

In conclusion, the translation techniques used by the translator can affect the quality of a translation product. In this research there are 27 data found. There are 25 data which are considered as accurate with a 2.57 average accuracy score. Only 2 data are considered quite accurate with 0.43 average accuracy score and no data considered not accurate in the research. The use of literal translation technique is not recommended since it will reduce the accuracy level of the translation work. In the future, the translator should be aware in deciding the most appropriate translation techniques to use in order to produce a good quality translation. Moreover, there are many ways to respond commanding turn verbally alongside with directive speech act. Future researchers can also use the opportunity to discuss them as a prospectus research.

\section{References}

Albir, A.H and Molina, L. (2002). Translation Technique Revisited: A Dynamic and Functionalist Approach. Meta, Vol. XLVII, No. 4. Barcelona: Universitat Autònoma de Barcelona.

Gulo, W. (1996). Metodologi Penelitian. Jakarta : PT Grasindo.

Larson, Mildred L. (1984). Meaning-Based Translation: A Guide to Cross-Language Equivalence. Lanham, MD: University Press of America.

Leech, Geoffrey. (1993). Prinsip-prinsip Pragmatik (edisi terjemahan oleh M.D.D. Oka). Jakarta: Universitas Indonesia.

Martin, George R. R. (1996). A Game of Thrones. New York: Bantam Books.

Martin, George R. R. (2015). Perebutan Takhta. Jakarta: Fantasious.

Nababan, Nuraeni, Sumardiono. (2012). "Pengembangan Model Penilaian Kualitas Terjemahan”. Jurnal Kajian Linguistik and Sastra, Vol. 24, No. 1, Juni 2012: 39-57.

Nida, E.A. \& Taber, C.R. (1982). The Theory and Practice of Translation. Leiden: E.J.Brili.

Santosa, Riyadi. (2014). Metode Penelitian Kualitatif Kebahasaan. Surakarta: Universitas Sebelas Maret. Sarwono, Sarlito Wirawan. (1995). Teori-teori Psikologi Sosial. Jakarta: PT RajaGrafindo Persada.

Schaffner, C and Adab B. (2000). Developing Translation Competence. John Benjamins B.V.: USA.

Searle, John. (1979). Expression and Meaning: Studies in the Theory of Speech Acts. Cambridge, England: Cambridge University.

Sutopo, H.B. (2002). Metode Penelitian Kualitatif. Surakarta.UNS Press. 
Yule, George. (2006). Pragmatik (edisi terjemahan oleh Indah Fajar Wahyuni dan Rombe Mustajab). Yogyakarta: Pustaka Pelajar.

\section{Copyrights}

Copyright for this article is retained by the author(s), with first publication rights granted to the journal. This is an open-access article distributed under the terms and conditions of the Creative Commons Attribution license (http://creativecommons.org/licenses/by/4.0/). 